\title{
Uranium modifies or not behavior and antioxidant status in the hippocampus of rats exposed since birth
}

\author{
Philippe Lestaevel, Bernadette Dhieux, Olivia Delissen, Marc Benderitter \\ and Jocelyne Aigueperse \\ Institut de Radioprotection et de Sûreté Nucléaire, Direction de la RadioProtection de l'Homme, \\ Service de Radiobiologie et d'Epidémiologie, Laboratoire de RadioToxicologie Expérimentale. IRSN, BP 17, 92262 \\ Fontenay-aux-Roses Cedex, France
}

(Received August 5, 2014; Accepted December 18, 2014)

\begin{abstract}
In view of the known sensitivity of the developing central nervous system to pollutants, we sought to assess the effects of exposure to uranium (U) - a heavy metal naturally present in the environment - on the behavior of young rats and the impact of oxidative stress on their hippocampus. Pups drank U (in the form of uranyl nitrate) at doses of 10 or $40 \mathrm{mg} . \mathrm{L}^{-1}$ for 10 weeks from birth. Control rats drank mineral water. Locomotor activity in an open field and practice effects on a rotarod device decreased in rats exposed to $10 \mathrm{mg} . \mathrm{L}^{-1}$ (respectively, $-19.4 \%$ and $-51.4 \%$ ) or $40 \mathrm{mg} . \mathrm{L}^{-1}$ (respectively, $-19.3 \%$ and $-55.9 \%)$ in compared with control rats. Anxiety $(+37 \%)$ and depressive-like behavior $(-50.8 \%)$ were altered by $\mathrm{U}$ exposure only at $40 \mathrm{mg} \cdot \mathrm{L}^{-1}$. Lipid peroxidation $(+35 \%)$ and protein carbonyl concentration $(+137 \%)$ increased significantly after exposure to $U$ at $40 \mathrm{mg}$. $\mathrm{L}^{-1}$. A significant increase in superoxide dismutase $(\mathrm{SOD},+122.5 \%)$ and glutathione peroxidase $(\mathrm{GPx},+13.6 \%)$ activities was also observed in the hippocampus of rats exposed to $40 \mathrm{mg}$. $\mathrm{L}^{-1}$. These results demonstrate that exposure to $\mathrm{U}$ since birth alters some behaviors and modifies antioxidant status.
\end{abstract}

Key words: Locomotor activity, Anxiety, Depression, Oxidative stress, Radionuclide

\section{INTRODUCTION}

Uranium (U) is an element belonging to the actinide group, found in rocks, soils, water, air, plants, and animals. The population may be chronically exposed to low levels of $\mathrm{U}$ from the environment through food (Kurttio et al., 2002). U may be also introduced into drinking water supplies through the mining and milling of $U$ ore (Cothern and Lappenbusch, 1983). Moreover, in recent years, the use of $U$ in nuclear power-reactors and munitions has given rise to a new exposure route for this heavy metal (López-Abente et al., 2001; McDiarmid et al., 2004; Abou-Donia et al., 2002). Although nephrotoxicity is considered to be the most serious potential effect of $U$ exposure (Diamond et al., 1989), it may have other possible adverse effects of $U$ on organisms. For example, it has been shown that $U$ is a developmental toxicant with dose-related fetal toxicity (Arfsten et al., 2001). U crosses the blood-brain barrier (Lemercier et al., 2003) and accumulates in the rat brain after chronic exposure (Pellmar et al., 1999a; Paquet et al., 2006), and several experimental studies have found that it has a toxic effect on the behavior of adult rats (Briner and Murray, 2005; Bellès et al., 2005; Houpert et al., 2005; Lestaevel et al., 2005). This behavioral toxicity is expressed by increased locomotor activity (Briner and Muray, 2005; Bellès et al., 2005), significantly decreased spatial working memory capacities (Houpert et al., 2005), increased anxiety (Houpert et al., 2005), and shorter paradoxical sleep (Lestaevel et al., 2005). In addition to the cerebral cortex (Lestaevel et al., 2013), the hippocampus also seems to be a major target of U-induced neurotoxicity (Pellmar et al., 1999b).

The hippocampus is a major component of the brain. It belongs to the limbic system and plays a number of important roles. It is involved in mood disorders, such as anxiety and depression (Deacon and Rawlins, 2005; Bannerman et al., 2004). Oxidative stress may be associated with these and other cognitive disturbances (Floyd, 1999; Thiels and Klann, 2002), and the deleterious effects of oxidative insult appear to affect the hippocampus strongly (Bonatto et al., 2005; Serrano and Klann, 2004). Oxidative stress is caused by oxidants, particular-

Correspondence: Philippe Lestaevel (E-mail: philippe.lestaevel@irsn.fr) 
ly reactive oxygen species (ROS) and reactive nitrogen species (RNS), which overload the antioxidant defense system developed by cells to counteract oxidation. Oxidative insult may disrupt cell structures and functions that depend on the critical redox balance. The reactive species can inflict significant oxidative damage, especially on membrane lipids, and cause lipid peroxidation (Videla and Fernández, 1988). Previous studies have demonstrated that chronic $U$ ingestion induces lipid peroxidation and antioxidative defense mechanisms in the brain of adult rats (Linares et al., 2007; Lestaevel et al., 2009).

Although immature brains are known to be more susceptible to some toxic effects, only a few published studies describe animals exposed to $U$ during this developmental period. Briner and Abboud have demonstrated that mice exposed to U during development, through exposure of their dams for two weeks before and after mating, show altered learning and habituation at 21 days of age (Briner and Abboud, 2002). Slight effects of U were also observed on the learning profiles of the offspring of adult rats exposed before mating, for passive avoidance and water maze tests (Albina et al., 2005; Sánchez et al., 2006). Certain environmental contaminants can induce and exacerbate developmental neurotoxic effects when these agents are present during a critical period of neonatal brain development (Eriksson, 1997; Eriksson et al., 2010). Rapid developmental and biochemical changes occur during the brain growth spurt (Eriksson, 2008), which for rats is the neonatal, during the first 3-4 weeks after birth. Thus, we decided to investigate the effects of exposure to U, including during this period. Exposure to U started just after the animals' birth and continued for 10 weeks. Their anxiety, depression, motor coordination, and locomotor activities were studied, as well as the redox environment of their hippocampi. This study used dosages of 10 and $40 \mathrm{mg} . \mathrm{L}^{-1}$ of $U$ in drinking water. The highest concentration of $U$ found naturally in mineral water is 12 mg.L-1 (Juntunen, 1991). These dosages were not considered nephrotoxic (Souidi et al., 2005).

\section{MATERIALS AND METHODS}

\section{Animals}

Experiments were conducted in accordance with the recommendations of the European Animal Care Commission (Act no. 87-848). All procedures were performed by scientists accredited by the French Ministry of Agriculture (license of first author, no. 92-254).

This study used pregnant female Sprague-Dawley rats (Charles River, L'Arbresle, France), individually housed during gestation under standard conditions $\left(21 \pm 1^{\circ} \mathrm{C}\right)$ with a 12-hr light/12-hr dark cycle (light-on from 08:00 to 20:00 hr), and their offspring. Animals had free access to food and water ad libitum.

Around $24 \mathrm{hr}$ before the birth of the pups, the female rats were subdivided into three groups $(n=14$ females for each group). One group was contaminated by mineral drinking water supplemented with $U$ in the form of uranyl nitrate (AREVA), which produced a dose of $10 \mathrm{mg} . \mathrm{L}^{-1}$ (about $0.25 \mathrm{mg} \cdot \mathrm{day}^{-1}$ per rat). The second group was contaminated with $U$ by drinking water at a dose of $40 \mathrm{mg} . \mathrm{L}^{-1}$ (about $1 \mathrm{mg}$.day ${ }^{-1}$ per rat). The specific activity of $\mathrm{U}$ is $1.4 \times 10^{-4} \mathrm{~Bq} \cdot \mathrm{g}^{-1}$, with an isotopic composition of ${ }^{234} \mathrm{U}=0.0055 \%,{ }^{235} \mathrm{U}=0.255 \%$, and ${ }^{238} \mathrm{U}=$ $99.74 \%$. Females were exposed to $U$ throughout the lactation period. Control female rats drank uncontaminated water. After weaning on postnatal day 21, male pups' exposure to U via drinking water (10 or $\left.40 \mathrm{mg} . \mathrm{L}^{-1}\right)$ continued until they reached 10 weeks of age. One male offspring per litter was assigned to behavioral tests $(n=12$ for each group, the same animal for all four tests). Health variables, i.e. body weight, water consumption, and food intake, were measured at the end of the pups' $U$ exposure (at age 10 weeks).

\section{Behavioral tasks}

Male pups ( $\mathrm{n}=12$ for each experimental group) underwent behavioral evaluation tests at age 10 weeks. Their behavioral functions were evaluated with four commonly used tests: the open-field test, the elevated plus-maze, the rotarod test, and the Porsolt test. Behavioral tasks were performed in a room with constant temperature $\left(21 \pm 1^{\circ} \mathrm{C}\right)$ and light conditions (60-W light). No test required food deprivation, reward, or punishment. The tests were recorded by a video camera and were read by a trained observer unaware of the exposure conditions.

\section{Open-field test}

During the first day of behavioral testing, locomotor and exploratory activities were assessed with an openfield test, the methodological details of which are reported elsewhere (Prut and Belzung, 2003). Briefly, each rat was moved from its home cage to the center of an openfield $(45 \mathrm{~cm} \times 45 \mathrm{~cm})$, equipped with invisible infrared beams, with lines every $2.5 \mathrm{~cm}$ and one line $16 \mathrm{~cm}$ high, monitored by an automated activity-monitoring system (Bioseb, Vitrolles, France). Counting occurred when the rat moved horizontally, showing predominantly locomotor behavior, or vertically (rearing), showing exploratory activity (Rocha and de Mello, 1994). The numbers of horizontal and rearing movements were recorded over a 20-min period. 
Behavioral effects and oxidative stress after postnatal exposure to uranium

\section{Elevated plus-maze}

The second day, anxiety-like behavior was evaluated by the elevated plus-maze, an apparatus that consists of two facing open arms $(50 \times 10 \mathrm{~cm})$ and two opposed enclosed arms without a roof $(50 \times 41 \times 10 \mathrm{~cm})$, with an open square $(10 \times 10 \mathrm{~cm})$ in the center. The maze is elevated $50 \mathrm{~cm}$ above the floor. For the test, each animal was placed in the center of the maze, facing one of the open arms. The number of entries and the time spent in open and closed arms was recorded for 5 min (Dunham and Miya, 1957).

\section{Rotarod test}

Motor coordination and a practice effect were evaluated on a rotarod the third day of the behavioral tests (Ugo Basile, Monvalle, Italy). For motor coordination, rats were placed on the rotarod at $5 \mathrm{rpm}$ without previous training. For the practice effect (learning ability), rats were then placed on the bar two more times the same day, again at $5 \mathrm{rpm}$. The time each animal remained on the rotating rod was recorded. The time limit was set at $3 \mathrm{~min}$ (Darnaudéry et al., 2004).

\section{Porsolt test}

The forced swimming test (or Porsolt test), which was the most stressful test applied in this study, was performed the fourth day. The rats were individually placed in a glass cylinder (height $60 \mathrm{~cm}$, diameter $40 \mathrm{~cm}$ ), containing enough water so the hind legs could not reach the bottom of the cylinder but the tail could. The water was maintained at $23-25^{\circ} \mathrm{C}$ and the rats were left for $10 \mathrm{~min}$. Immobility was measured during the last $5 \mathrm{~min}$ of the test. The Porsolt test was administered once. The animal was judged to be immobile when it floated in an upright position and made only minimal movements to keep its head above water (Bourin et al., 2004).

\section{Oxidative stress analyses}

After behavioral tasks, animals were anesthetized by inhalation of $95 \%$ air $/ 5 \%$ isoflurane (Forène, Abbott, Rungis, France). After decapitation, the hippocampus was dissected out in ice, frozen immediately in liquid nitrogen, and stored at $-80^{\circ} \mathrm{C}$ for later biochemical analyses ( $\mathrm{n}=8$ /group). The tissues were homogenized in ice-cold $0.1 \mathrm{M}$ phosphate-buffered saline (PBS, $\mathrm{pH}$ 7.4) containing $1 \mathrm{mM}$ EDTA. The homogenates were centrifuged at $10,000 \mathrm{~g}$ for $15 \mathrm{~min}$ at $4^{\circ} \mathrm{C}$, and the supernatants were collected for analysis. Protein concentrations were determined by the Bradford method, with bovine serum albumin as the standard.

\section{Indicators of oxidative stress}

As an index of lipid peroxidation, we measured the concentrations of hydroperoxides. Concentrations were determined with a commercial kit supplied by Cayman Chemical (Interchim, Montluçon, France). This lipid hydroperoxide assay kit measures hydroperoxides that directly utilize redox reactions with ferrous ions to produce ferric ions. The resulting ferric ions were detected with thiocyanate ion as the chromogen. Each assay was performed in duplicate, and concentrations are expressed as $\mu \mathrm{M}$ (Lestaevel et al., 2009).

Highly reactive free radical species can oxidize lipids but also proteins. The most general indicator and by far the most commonly used marker of protein oxidation is protein carbonyl concentration, which we measured with a commercial kit from Cayman Chemical (Interchim). This colorimetric assay kit used the reaction between 2,4dinitrophenylhydrazine (DNPH) and protein carbonyls. DNPH reacts with protein carbonyls, to produce the corresponding hydrazine, which is quantified spectrophotometrically at an absorbance of $385 \mathrm{~nm}$. Each assay was performed in duplicate, and concentrations are expressed in nmoles/mg of proteins.

\section{Antioxidant enzyme activities}

We assessed the activity of superoxide dismutase (SOD), catalase (CAT), and glutathione peroxidase (GPx), using commercial kits from Cayman Chemical (Interchim), as previously described (Lestaevel et al., 2009).

SOD activity was estimated with a tetrazolium salt to detect the superoxide radicals generated by xanthine oxidase and hypoxanthine. Enzyme units were recorded as U.mg-1 protein. The method for CAT activity is based on the reaction of the enzyme with methanol in the presence of an optimal concentration of $\mathrm{H}_{2} \mathrm{O}_{2}$. The formaldehyde produced was measured by a spectrophotometer, and the CAT activity is expressed in nmol of formaldehyde. $\mathrm{min}^{-1}$. $\mathrm{mg}^{-1}$ protein. GPx activity was determined by measuring the rate of NADPH oxidation in a spectrophotometer at $340 \mathrm{~nm}$, and the results are expressed as nmol NADPH oxidized. $\mathrm{min}^{-1} \cdot \mathrm{mg}^{-1}$ protein.

\section{Uranium analyses}

After addition of concentrated nitric acid (Ultrapur, JT Becker) and hydrogen peroxide 30\% (Normapur, VWR), brain samples were digested in a microwave oven (Ethos TC; Milestone, Bergamo, Italy) by the following procedure: microwave power at $1,000 \mathrm{~W}$, ramp $10 \mathrm{~min}$ to reach $200^{\circ} \mathrm{C}$, and then hold at $200^{\circ} \mathrm{C}$ for $20 \mathrm{~min}$. $\mathrm{U}$ content in mineralized sam- 
ples was determined with an inductively coupled plasma mass spectrometer (ICPMS-VGPQ, EXCELL, ThermoElectron, Courtaboeuf, France) with bismuth $\left(1 \mu \mathrm{g} . \mathrm{L}^{-1}\right)$ as an internal standard, according to previously reported methods (Becker et al., 2005). For U, the ICPMS detection limit is $10^{-4} \mu \mathrm{g} . \mathrm{L}^{-1}$. Values are expressed as nanograms per gram of fresh sample material. This ICP-MS protocol has been previously described in the literature (Karpas et al., 2005).

\section{Statistical analyses}

In all experiments, data are expressed as mean \pm S.E.M., and the effect of $U$ is assessed by one-way ANOVA, followed by a Student-Newman-Keuls post hoc test, whenever appropriate necessary. Differences were considered significant if $\mathrm{p}<0.05$ or $\mathrm{p}<0.01$.

\section{RESULTS}

\section{Health indicators}

Body weight and drinking water and food consumption were monitored at the end of $U$ exposure (at 10 weeks of age in pups). Neither weight nor diets differed between the U-exposed (10 or $40 \mathrm{mg} . \mathrm{L}^{-1}$ ) and the control rats (data not shown).

\section{Behavioral tasks \\ Open-field activity}

The locomotor and exploratory behaviors of rats were assessed by the total number of lines crossed and the total number of rearing movements in the open field. Fig. 1 shows the results for both indicators.

Rats exposed to the high $U$ dose $\left(40 \mathrm{mg} . \mathrm{L}^{-1}\right)$ for 10 weeks after birth crossed significantly fewer lines than the controls during the 10 last minutes of the test $(-19.3 \%$ at $15 \mathrm{~min}$ and $-18.5 \%$ at $20 \mathrm{~min}$ ) (Fig. 1A). This effect was also observed in rats exposed to the low $\mathrm{U}$ dose $\left(10 \mathrm{mg} \cdot \mathrm{L}^{-1}\right)$ after $5(-21.6 \%)$ and $15(-19.4 \%) \mathrm{min}$ (Fig. 1A).

The total number of rearing movements in the open field did not differ significantly in rats exposed to 10 or $40 \mathrm{mg} . \mathrm{L}^{-1}$ and control animals (Fig. 1B).

\section{Elevated plus-maze}

The anxiety-like behavior of rats was assessed in the elevated plus-maze by the number of entries into closed arms and the time spent in closed arms. The latter indicator is shown in Fig. 2.

The number of closed-arm entries did not differ between rats exposed to either $\mathrm{U}$ dose and controls (data not shown). However, rats exposed to $40 \mathrm{mg} . \mathrm{L}^{-1}$ of $\mathrm{U}$, but
Cumulative locomotor activity

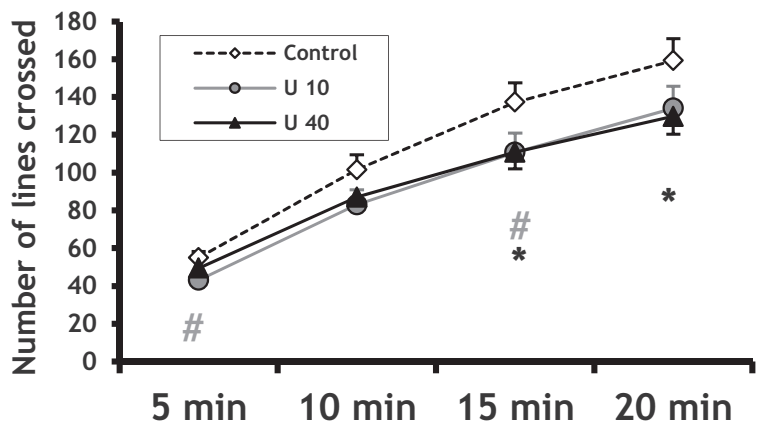

Cumulative exploratory activity B

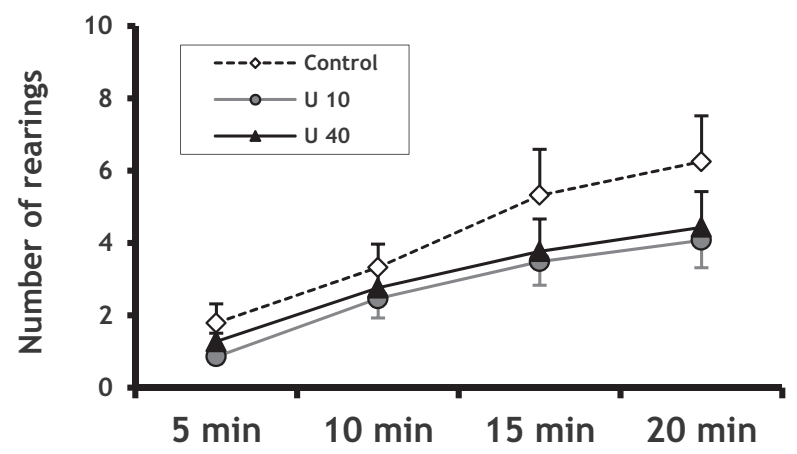

Fig. 1. Total activity of rats exposed to $U$ from birth for 10 weeks. Panel A shows the number of lines crossed, reflecting locomotor activity. The number of rearing is presented in panel B and reflects exploratory activity. The data are presented as mean \pm S.E.M.; $\mathrm{n}=12$ for each group; $\# p<0.05$, significant difference between U10 group and control; * $\mathrm{p}<0.05$, significant difference between U40 group and control.

not those exposed to $10 \mathrm{mg} . \mathrm{L}^{-1}$, spent significantly more time in closed arms than the controls $(17.3 \pm 1.5 \mathrm{sec}$, versus $12.6 \pm 1.5 \mathrm{sec}, \mathrm{p}<0.05$ ) (Fig. 2).

\section{Rotarod test}

The rats' motor coordination and practice effect were assessed by the time spent on the rod. The results are shown in Fig. 3.

Motor coordination at $5 \mathrm{rpm}$ during the first trial did not differ significantly in rats exposed to $U$ at 10 or 40 mg.L L $^{-1}$ compared with controls (Fig. 3).

The time on the rod increased significantly over the trials at $5 \mathrm{rpm}$ for the control rats (Fig. 3), but not for the U-exposed rats (Fig. 3). During the third trial, the time spent on the rotarod decreased significantly in the rats 
Behavioral effects and oxidative stress after postnatal exposure to uranium

Elevated plus-maze: anxiety

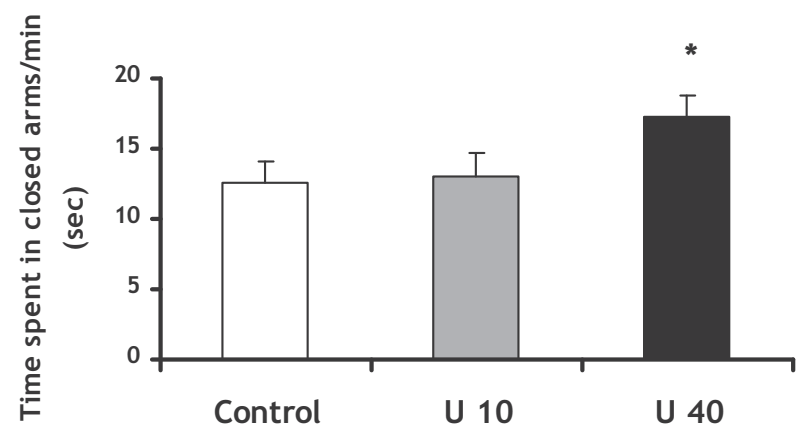

Fig. 2. Anxiety like-behavior of rats exposed to $U$ from birth for 10 weeks. The time spent in closed arms of the elevated plus-maze is expressed in seconds and reflects the anxiety level. The data are presented as mean \pm S.E.M.; $\mathrm{n}=12$ for each group; ${ }^{*} \mathrm{p}<0.05$, significant difference from control.

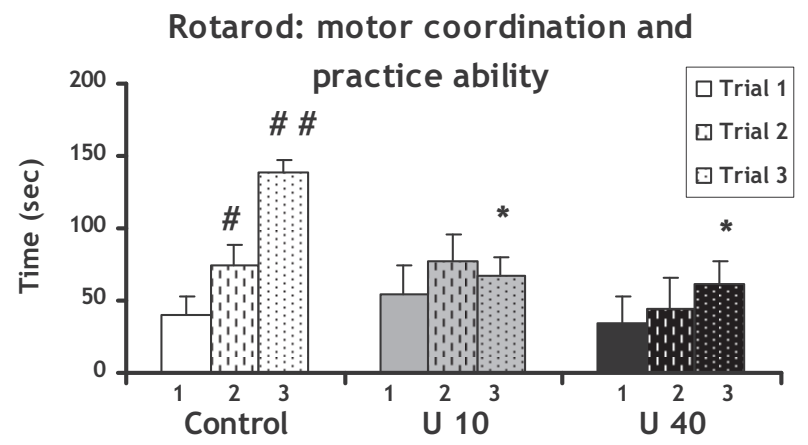

Fig. 3. Rotarod task of rats exposed to $U$ from birth for 10 weeks. Motor coordination and learning ability (practice effect) are expressed in seconds. The data are presented as mean \pm S.E.M.; $\mathrm{n}=12$ for each group; $\# \mathrm{p}<0.05$ and $\# \# \mathrm{p}<0.01$, significant difference from trial $1 ; * \mathrm{p}<0.05$, significant difference between $\mathrm{U} 10$ or U40 groups and control.

exposed to $U$ at 10 and $40 \mathrm{mg} \cdot \mathrm{L}^{-1}$ (respectively, $-51.4 \%$ and $-55.9 \%, p<0.05$ ) compared to controls (Fig. 3 )

\section{Porsolt test}

Immobility time in the Porsolt test evaluates depression-like behavior. This indicator is shown in Fig. 4.

At 10 weeks of age, the immobility time recorded during the last 5 min of the test was significantly lower in the group exposed to $40 \mathrm{mg} . \mathrm{L}^{-1}$ compared with the control group $(-50.8 \%, p<0.05)$ (Fig. 4). No significant difference was observed in the group exposed at a dose of $10 \mathrm{mg} . \mathrm{L}^{-1}$. This result indicates that exposure to $\mathrm{U}$ at $40 \mathrm{mg} . \mathrm{L}^{-1}$ reduced depressive-like behavior.

\section{Porsolt test: depressive like-behavior}

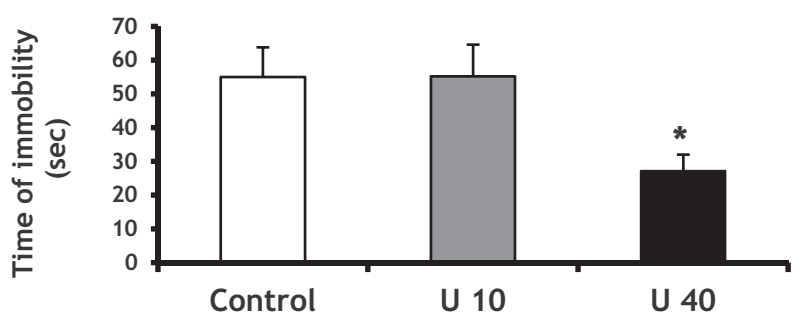

Fig. 4. Depression-like behavior of rats exposed to U from birth for 10 weeks. Time of immobility is expressed in seconds and reflects the depression level. The data are presented as mean \pm S.E.M.; $n=12$ for each group; $* \mathrm{p}<0.05$, significant difference from control.

\section{Oxidative damage indicator}

Lipid peroxidation levels in the hippocampus of rats exposed to $\mathrm{U}$ at $40 \mathrm{mg} \cdot \mathrm{L}^{-1}$ for 10 weeks after birth increased significantly compared to control animals $(100.3 \pm 9.3 \mu \mathrm{M}$ versus $74.1 \pm 7.1 \mu \mathrm{M}, \mathrm{p}<0.05)$. No significant increase was observed in rats exposed to $U$ at 10 mg.L -1 $^{-1}(91.2 \pm 9.2 \mu \mathrm{M}$ versus $74.1 \pm 7.1 \mu \mathrm{M})$.

Protein carbonyl concentrations in the hippocampus of rats exposed to $\mathrm{U}$ at $40 \mathrm{mg} . \mathrm{L}^{-1}$ for 10 weeks since birth increased significantly comparison to control animals $(0.488 \pm 0.044 \mathrm{nmol} / \mathrm{mg}$ prot. versus $0.206 \pm 0.039 \mathrm{nmol} /$ mg prot., $\mathrm{p}<0.05)$. Again, no significant increase was observed for the group exposed to $U$ at $10 \mathrm{mg} . \mathrm{L}^{-1}(0.269$ 0.037 versus $0.206 \pm 0.039 \mathrm{nmol} / \mathrm{mg}$ prot).

\section{Antioxidant enzymes}

Exposure to $\mathrm{U}$ at $40 \mathrm{mg}$. $\mathrm{L}^{-1}$ induced a significant increase $(+122.5 \%, \mathrm{p}<0.05)$ in the rats' SOD activity, compared to that of the controls (Fig. 5). GPx activity was also higher $(+13.6 \%, \mathrm{p}<0.05)$ in the hippocampus of these rats (Fig. 5). Catalase activity, however, was not significantly modified in rats exposed to $U$ at $40 \mathrm{mg}$. $\mathrm{L}^{-1}$ compared to control rats (Fig. 5).

Exposure to $\mathrm{U}$ at $10 \mathrm{mg} \cdot \mathrm{L}^{-1}$ for 10 weeks did not result in any difference with controls in SOD, GPx, or catalase activities (Fig. 5).

\section{Uranium in tissues}

$\mathrm{U}$ levels in the whole brain were significantly higher in rats exposed to $\mathrm{U}$ (40 mg. $\mathrm{L}^{-1}$ group: $2.49 \pm 0.43 \mathrm{ng} . \mathrm{g}^{-1}$; 10 mg.L $L^{-1}$ group: $2.02 \pm 0.61$ ng. g $^{-1} ; \mathrm{p}<0.05 ; \mathrm{n}=6$ per group) compared with controls $\left(1.07 \pm 0.05 \mathrm{ng} . \mathrm{g}-{ }^{1} ; \mathrm{n}=6\right)$. 


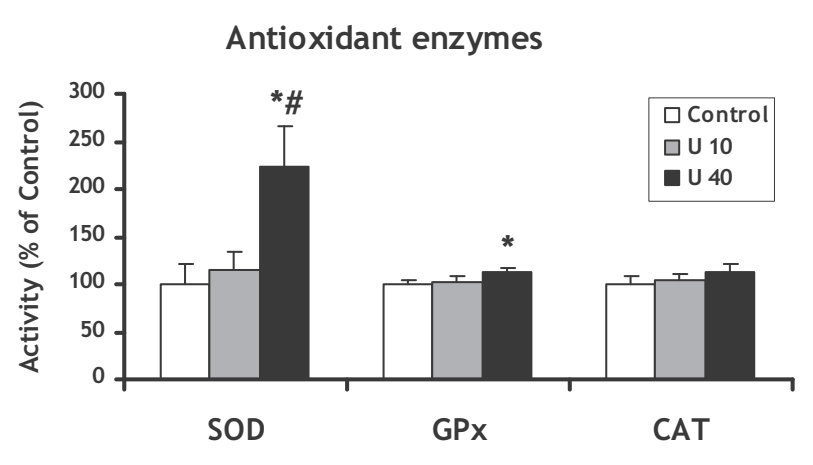

Fig. 5. Enzymatic activity of catalase (CAT), superoxide dismutase (SOD) and glutathione peroxidase (GPx) in hippocampus of rats exposed to $U$ from birth for 10 weeks. Activities are expressed as a percentage of activity in the controls. The data are presented as mean \pm S.E.M.; $\mathrm{n}=8$ for each group; ${ }^{*}$ and $\# \mathrm{p}<0.05$, significant difference between U40 group and control group or U 10 group, respectively.

The $\mathrm{U}$ level in the hippocampus was significantly higher after exposure to $\mathrm{U}$ in the $40 \mathrm{mg} . \mathrm{L}^{-1}$ group $\left(2.79 \pm 0.13\right.$ ng. $\left.\mathrm{g}^{-1} ; \mathrm{n}=6\right)$ compared to the control $(1.22 \pm$ $\left.0.22 \mathrm{ng} . \mathrm{g}^{-1} ; \mathrm{n}=6\right)$. No significant difference was observed between the 10-mg U.L-1 group $\left(1.91 \pm 0.32\right.$ ng.g $\left.\mathrm{g}^{-1} ; \mathrm{n}=6\right)$ and the control group.

Protein carbonyl concentrations were directly correlated with uranium levels in the hippocampus (Fig. 6).

\section{DISCUSSION}

Our results clearly show that $\mathrm{U}$ exposure from birth to 10 weeks, during a critical period of perinatal brain development, induces behavioral alterations in rats. This is a sensitive period for exposure to low levels of environmental contaminants (Eriksson et al., 2010). The higher levels of lipid peroxidation in the hippocampus are indirect evidence of oxidative damage that might play a role in these behavioral changes.

This study investigated the potential adverse effects of $U$ on the behavior of rats exposed from birth. The first indicator we studied is total activity. Activity levels measured in an open-field test have been widely used in behavioral studies (Prut and Belzung, 2003). The openfield procedure involves estimating primary motor activity, evaluated from the number of line crossings, and exploratory activity, evaluated from the number of rearing movements onto the hind limbs. Here we observed significantly less locomotor activity in rats exposed to $\mathrm{U}$ at 10 or $40 \mathrm{mg} . \mathrm{L}^{-1}$. Previously published results are sim-

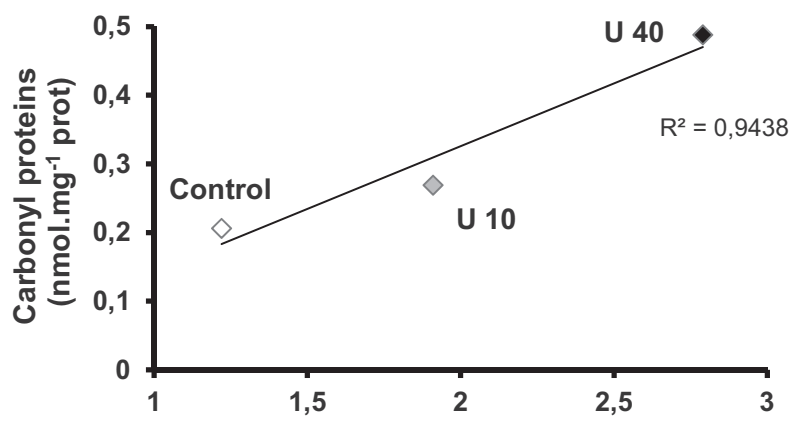

Uranium content (ng.g-1 hippocampus)

Fig. 6. Correlation and linear regression for protein carbonyl concentration and uranium levels in hippocampus of rats exposed to $U$ at 40 or $10 \mathrm{mg} . \mathrm{L}^{-1}$ from birth for 10 weeks. Carbonyl protein concentration is expressed in nmol.mg ${ }^{-1}$ protein. The uranium level is expressed in ng. $\mathrm{g}^{-1}$.

ilar. In mice exposed to $\mathrm{U}$ during gestation and lactation, the open-field activity was about $20 \%$ lower than in controls (Briner and Abboud, 2002). This reduced activity was reported at a dosage of $75 \mathrm{mg} \mathrm{U} . \mathrm{L}^{-1}$ in drinking water and appeared earlier in mice aged 3 weeks. The opposite result, i.e. hyperactivity, has been described in adult rats exposed to U. Locomotor activity and rearing movements increased by $100 \%$ in an open field over a 5 -min observation period in adult rats exposed to $150 \mathrm{mg} \mathrm{U}^{\mathrm{L}} \mathrm{L}^{-1}$ for either 2 weeks or 6 months (Briner and Murray, 2005). Similarly, a $25 \%$ increase in locomotor activity and a $35 \%$ increase in rearing movements have been reported over a 5-15 min observation period in an open field in rats exposed to repeated $\mathrm{U}$ inhalation $(30 \mathrm{~min}$ inhalation at $197 \mathrm{mg} . \mathrm{m}^{-3}, 4$ days a week for 3 weeks) (Monleau et al., 2005). These differences in motor activity were unexpected. It seems likely that the detection of hypo- or hyper-activity in rats depends on the time exposure starts and the uranium dose used.

In the rotarod task, the U-exposed rats showed significant impairment in their practice effect in terms of synchronized walking. This deficit appears to indicate an impairment in adaptive ability. For motor coordination itself during the trial, none of the U-exposed rats (at either 10 or $40 \mathrm{mg} . \mathrm{L}^{-1}$ ) showed any significant deficit in motor coordination compared with control animals. Moreover, the animals walked normally, showing no muscular weakness. The lack of effect on motor coordination of U-exposed rats in the rotarod is consistent with data from the literature showing that low-dose exposure to other heavy 
Behavioral effects and oxidative stress after postnatal exposure to uranium

metals does not produce gross motor deficits (Goulet et al., 2003). One possibility is that the rotarod task was not sensitive enough to detect weak impairment of motor behavior caused by heavy metals.

In the elevated plus-maze test, our study suggests that exposure to $U$ produces an increase of anxiety-like behavior at the highest dose used. This result is not consistent with previous data showing no significant effect of $\mathrm{U}$ exposure at a dose of $40 \mathrm{mg} . \mathrm{L}^{-1}$ on anxiety-like behavior in adult rats (Houpert et al., 2005). We should bear in mind that the rat's biochemical system is not complete until 4 weeks after birth (Giorgi et al., 1987). This might explain the differences in some behavioral effects detected in rats exposed from birth or at adult age.

We also analyzed the effects of $U$ on depressive behavior, a topic never addressed in previous studies. For this purpose, we used the forced swimming task, generally considered to test an animal model of depression (Porsolt, 2000). Data from this task reveals that animals exposed to the higher $U$ dose showed less immobility. These unexpected findings suggest decreased susceptibility to depressive-like behavior. An interaction on the molecular level has been demonstrated between corticoreleasing factor and serotonin receptors in the presence of anxiety-like behavior (Magalhaes et al., 2010) and could cause abnormal brain signals that could have an effect on depressive-like behavior. This reduction in depressivelike behavior might thus be related, directly or indirectly, to the increase of anxiety. Previously, it has been suggested that the increased rapid-eye-movement sleep observed in adult rats exposed to $U$ might be linked to depression (Lestaevel et al., 2005). Depressive syndromes have been reported in Gulf War veterans (McDiarmid et al., 2002). Other heavy metals induce also depressive-like behaviors in mouse offspring (Onishchenko et al., 2007; Martinez et al., 2008). It has been suggested that impairment in hippocampal function may be involved in the etiology of depression (Warner-Schmidt and Duman, 2006). Further in-depth studies are needed into the potential effects of developmental $U$ exposure on emotional behavior. Finally, while the hippocampus is important in many of the behaviors examined, so are other regions, such as the amygdal body or striatum, and they should be examined.

Several causes might explain the behavioral effects we observed. A correlation between lipid peroxidation - a marker of oxidative stress measured by the thiobarbituric acid (TBA) assay — and locomotor activity has previously been demonstrated after ingestion of $\mathrm{U}$ in adult animals (150 mg.L $\mathrm{L}^{-1}$ ) for 2 weeks (Briner and Murray, 2005). Here we quantified lipid peroxidation by the direct determination of hydroperoxides, which was significantly higher in animals exposed to the higher $U$ dose. In the same experimental conditions, the protein carbonyl concentration also rose significantly. After $\mathrm{U}$ exposure at $40 \mathrm{mg} . \mathrm{L}^{-1}$ it was correlated with higher uranium levels in the hippocampus than after $U$ exposure at $10 \mathrm{mg} . \mathrm{L}^{-1}$. These results might suggest that oxidative stress plays a key role in behavior impairment. Several previous studies have shown that oxidative stress can provoke anxiety-like behavior in rodents. For example, the consumption of a highly palatable diet enriched with sucrose increased protein oxidation in the frontal cortex of rats and induced anxiety-like behavior in the dark/light choice (Souza et al., 2007). A deletion of the p66Shc longevity gene in mice, which results in lower levels of oxidative stress and an extended life span, decreased anxietyrelated behavior (Berry et al., 2007). These data suggest an association between oxidative stress and elevated plusmaze performance, but not necessarily a cause-and-effect relation. Antioxidative defense mechanisms can be activated to counteract oxidative stress. Here, SOD and GPX activity were significantly higher in the hippocampus of rats exposed to $U$ (40 mg. $\left.\mathrm{L}^{-1}\right)$ for 10 weeks after their birth than in controls. Similar results have been observed in the brain of rats exposed to $U$ at adult age (Linares et al., 2007; Lestaevel et al., 2009). The accumulation of $U$ in the hippocampus suggests that $U$ has a direct neurotoxic effect on the central nervous system. It has previously been shown that $\mathrm{U}$ may be toxic to this cerebral structure (Pellmar et al., 1999b). Finally, the lack of any significant effect on oxidative stress by exposure to $10 \mathrm{mg} . \mathrm{L}^{-1}$ of $\mathrm{U}$ suggests in the context of this study that oxidative stress is not the only causative factor involved in these behavioral disturbances.

In conclusion, our data indicate that exposure to $\mathrm{U}$ from birth to 10 weeks induces behavioral and neurochemical consequences. Some precautions should be taken regarding chronic exposure to this contaminants at environmental doses. Finally, since males are less resistant than females to U-mediated toxicity (Briner and Murray, 2005), this study focused only on male pups, but further experiments on females might also be useful.

\section{ACKNOWLEDGMENTS}

This study forms part of the ENVIRHOM research programme supported by the Institute for Radioprotection and Nuclear Safety (IRSN). The authors thank T. Loiseau and F. Voyer for animal care. 
Conflict of interest---- The authors declare that there is no conflict of interest.

\section{REFERENCES}

Abou-Donia, M.B., Dechkovskaia, A.M., Goldstein, L.B., Shah, D.U., Bullman, S.L. and Khan, W.A. (2002): Uranyl acetateinduced sensorimotor deficit and increased nitric oxide generation in the central nervous system in rats. Pharmacol. Biochem. Behav., 72, 881-890.

Albina, M.L., Bellés, M., Linares, V., Sánchez, D.J. and Domingo, J.L. (2005): Restraint stress does not enhance the uranium-induced developmental and behavioral effects in the offspring of uranium-exposed male rats. Toxicology, 215, 69-79.

Arfsten, D.P., Still, K.R. and Ritchie, G.D. (2001): A review of the effects of uranium and depleted uranium exposure on reproduction and fetal development. Toxicol. Ind. Health, 17, 180-191.

Bannerman, D.M., Rawlins, J.N., McHugh, S.B., Deacon, R.M., Yee, B.K., Bast, T., Zhang, W.N., Pothuizen, H.H. and Feldon, J. (2004): Regional dissociations within the hippocampus--memory and anxiety. Neurosci. Biobehav. Rev., 28, 273-283.

Becker, J.S., Zoriy, M.V., Pickhardt, C., Palomero-Gallagher, N. and Zilles, K. (2005): Imaging of copper, zinc, and other elements in thin section of human brain samples (hippocampus) by laser ablation inductively coupled plasma mass spectrometry. Anal. Chem., 77, 3208-3216.

Bellés, M., Albina, M.L., Linares, V., Gómez, M., Sánchez, D.J. and Domingo, J.L. (2005): Combined action of uranium and stress in the rat. I. Behavioral effects. Toxicol. Lett., 158, 176-185.

Berry, A., Capone, F., Giorgio, M., Pelicci, P.G., de Kloet, E.R., Alleva, E., Minghetti, L. and Cirulli, F. (2007): Deletion of the life span determinant $\mathrm{p} 66 \mathrm{Shc}$ prevents age-dependent increases in emotionality and pain sensitivity in mice. Exp. Gerontol., 42, $37-45$.

Bonatto, F., Polydoro, M., Andrades, M.E., da Frota Júnior, M.L., Dal-Pizzol, F., Rotta, L.N., Souza, D.O., Perry, M.L. and Moreira, J.C. (2005): Effect of protein malnutrition on redox state of the hippocampus of rat. Brain Res., 1042, 17-22.

Bourin, M., Mocaër, E. and Porsolt, R. (2004): Antidepressant-like activity of S 20098 (agomelatine) in the forced swimming test in rodents: involvement of melatonin and serotonin receptors. J. Psychiatry Neurosci., 29, 126-133.

Briner, W. and Abboud, B. (2002): Behavior of juvenile mice chronically exposed to depleted uranium. In: Khassanova, L., Collery, P., Maymard, I., Khassanova, Z., Etienne, J.C., ed. Metal Ions in Biology and Medicine, vol. 7, John Libby Eurotext, Paris, 353356.

Briner, W. and Murray, J. (2005): Effects of short-term and longterm depleted uranium exposure on open-field behavior and brain lipid oxidation in rats. Neurotoxicol. Teratol., 27, 135-144.

Cothern, C.R. and Lappenbusch, W.L. (1983): Occurrence of uranium in drinking water in the U.S., Health Phys., 45, 89-99.

Darnaudéry, M., Dutriez, I., Viltart, O., Morley-Fletcher, S. and Maccari, S. (2004): Stress during gestation induces lasting effects on emotional reactivity of the dam rat. Behav. Brain Res., 153, 211-216.

Deacon, R.M. and Rawlins, J.N. (2005): Hippocampal lesions, species-typical behaviours and anxiety in mice. Behav. Brain Res., 156, 241-249.

Diamond, G.L., Morrow, P.E., Panner, B.J., Gelein, R.M. and Baggs, R.B. (1989): Reversible uranyl fluoride nephrotoxicity in the Long Evans rat. Fundam. Appl. Toxicol., 13, 65-78.

Dunham, N.W. and Miya, T.S. (1957): A note on a simple apparatus for detecting neurological deficit in rats and mice. J. Am. Pharm. Assoc., 46, 208-209.

Eriksson, P., Fischer, C., Stenerlöw, B., Fredriksson, A. and SundellBergman, S. (2010): Interaction of gamma-radiation and methyl mercury during a critical phase of neonatal brain development in mice exacerbates developmental neurobehavioural effects. Neurotoxicology, 31, 223-229.

Eriksson, P. (1997): Developmental neurotoxicity of environmental agents in the neonate. Neurotoxicology, 18, 719-726.

Eriksson, P. (2008): Developmental neurotoxicity of PCBs in mice: critical period of brain development and effects of interaction. In: Hansen LG and Robertson LW, ed. PCBs: human and environmental disposition and toxicology, University of Illinois Press, Urbana and Chicago, 172-185.

Floyd, R.A. (1999): Antioxidants, oxidative stress, and degenerative neurological disorders. Proc. Soc. Exp. Biol. Med., 222, 236245.

Giorgi, O., De Montis, G., Porceddu, M.L., Mele, S., Calderini, G., Toffano, G. and Biggio, G. (1987) : Developmental and age-related changes in D1-dopamine receptors and dopamine content in the rat striatum. Brain Res., 432, 283-290.

Goulet, S., Doré, F.Y. and Mirault, M.E. (2003): Neurobehavioral changes in mice chronically exposed to methylmercury during fetal and early postnatal development. Neurotoxicol. Teratol., 25, 335-347.

Houpert, P., Lestaevel, P., Bussy, C., Paquet, F. and Gourmelon, P. (2005): Enriched but not depleted uranium affects central nervous system in long-term exposed rat. Neurotoxicology, 26, 10151020.

Juntunen, R. (1991): Uranium and radon in wells drilled into bedrock in southern Finland. Report of Investigation 98. Espoo: Geologian Tutkimuskimusteskus.

Karpas, Z., Lorber, A., Sela, H., Paz-Tal, O., Hagag, Y., Kurttio, P. and Salonen, L. (2005): Measurement of the $234 \mathrm{U} / 238 \mathrm{U}$ ratio by MC-ICPMS in drinking water, hair, nails, and urine as an indicator of uranium exposure source. Health Phys., 89, 315-321.

Kurttio, P., Auvinen, A., Salonen, L., Saha, H., Pekkanen, J., Mäkeläinen, I., Väisänen, S.B., Penttilä, I.M. and Komulainen, H. (2002): Renal effects of uranium in drinking water. Environ. Health Perspect., 110, 337-342.

Lemercier, V., Millot, X., Ansoborlo, E., Ménétrier, F., Flüry-Hérard, A., Rousselle, Ch. and Scherrmann, J.M. (2003): Study of uranium transfer across the blood-brain barrier. Radiat. Prot. Dosimetry, 105, 243-245.

Lestaevel, P., Bussy, C., Paquet, F., Dhieux, B., Clarençon, D., Houpert, P. and Gourmelon, P. (2005): Changes in sleepwake cycle after chronic exposure to uranium in rats. Neurotoxicol. Teratol., 27, 835-840.

Lestaevel, P., Romero, E., Dhieux, B., Ben Soussan, H., Berradi, H., Dublineau, I., Voisin, P. and Gourmelon, P. (2009): Different pattern of brain pro-/anti-oxidant activity between depleted and enriched uranium in chronically exposed rats. Toxicology, 258, 1-9.

Lestaevel, P., Bensoussan, H., Dhieux, B., Delissen, O., Vacher, C.M., Dublineau, I., Voisin, P. and Taouis, M. (2013): Cerebral cortex and hippocampus respond differently after post-natal exposure to uranium. J. Toxicol. Sci., 38, 803-811.

Linares, V., Sánchez, D.J., Bellés, M., Albina, L., Gómez, M. and Domingo, J.L. (2007): Pro-oxidant effects in the brain of rats concurrently exposed to uranium and stress. Toxicology, 236, 
Behavioral effects and oxidative stress after postnatal exposure to uranium

$82-91$.

López-Abente, G., Aragonés, N. and Pollán, M. (2001): Solid-tumor mortality in the vicinity of uranium cycle facilities and nuclear power plants in Spain. Environ. Health Perspect., 109, 721-729.

Magalhaes, A.C., Holmes, K.D., Dale, L.B., Comps-Agrar, L., Lee, D., Yadav, P.N., Drysdale, L., Poulter, M.O., Roth, B.L., Pin, J.P., Anisman, H. and Ferguson, S.S. (2010): CRF receptor 1 regulates anxiety behavior via sensitization of 5-HT2 receptor signaling. Nat. Neurosci., 13, 622-629.

Martinez, E.J., Kolb, B.L., Bell, A., Savage, D.D. and Allan, A.M. (2008): Moderate perinatal arsenic exposure alters neuroendocrine markers associated with depression and increases depressive-like behaviors in adult mouse offspring. Neurotoxicology, 29, 647-655.

McDiarmid, M.A., Hooper, F.J., Squibb, K., McPhaul, K., Engelhardt, S.M., Kane, R., DiPino, R. and Kabat, M. (2002): Health effects and biological monitoring results of Gulf War veterans exposed to depleted uranium. Mil. Med., 167, 123-124.

McDiarmid, M.A., Squibb, K. and Engelhardt, S.M. (2004): Biologic monitoring for urinary uranium in gulf war I veterans. Health Phys., 87, 51-56.

Monleau, M., Bussy, C., Lestaevel, P., Houpert, P., Paquet, F. and Chazel, V. (2005): Bioaccumulation and behavioural effects of depleted uranium in rats exposed to repeated inhalations. Neurosci. Lett., 390, 31-36.

Onishchenko, N., Tamm, C., Vahter, M., Hökfelt, T., Johnson, J.A., Johnson, D.A. and Ceccatelli, S. (2007): Developmental exposure to methylmercury alters learning and induces depressionlike behavior in male mice. Toxicol. Sci., 97, 428-437.

Paquet, F., Houpert, P., Blanchardon, E., Delissen, O., Maubert, C., Dhieux, B., Moreels, A.M., Frelon, S. and Gourmelon, P. (2006): Accumulation and distribution of uranium in rats after chronic exposure by ingestion. Health Phys., 90, 139-147.

Pellmar, T.C., Fuciarelli, A.F., Ejnik, J.W., Hamilton, M., Hogan, J., Strocko, S., Emond, C., Mottaz, H.M. and Landauer, M.R. (1999a): Distribution of uranium in rats implanted with depleted uranium pellets. Toxicol. Sci., 49, 29-39.

Pellmar, T.C., Keyser, D.O., Emery, C. and Hogan, J.B. (1999b):
Electrophysiological changes in hippocampal slices isolated from rats embedded with depleted uranium fragments. Neurotoxicology, 20, 785-792.

Porsolt, R.D. (2000): Animal models of depression: utility for transgenic research. Rev. Neurosci., 11, 53-58.

Prut, L. and Belzung, C. (2003): The open field as a paradigm to measure the effects of drugs on anxiety-like behaviors: a review. Eur. J. Pharmacol., 463, 3-33.

Rocha, J.B. and de Mello, C.F. (1994): Handling during suckling alters rat behavior but does not reverse the deleterious effects of undernutrition on naltrexone-induced inhibition of exploratory activity. Int. J. Vitam. Nutr. Res., 64, 152-156.

Sánchez, D.J., Bellés, M., Albina, M.L., Gómez, M., Linares, V. and Domingo, J.L. (2006): Exposure of pregnant rats to uranium and restraint stress: effects on postnatal development and behavior of the offspring. Toxicology, 228, 323-332.

Serrano, F. and Klann, E. (2004): Reactive oxygen species and synaptic plasticity in the aging hippocampus. Ageing Res. Rev., 3, 431-443.

Souidi, M., Gueguen, Y., Linard, C., Dudoignon, N., Grison, S., Baudelin, C., Marquette, C., Gourmelon, P., Aigueperse, J. and Dublineau, I. (2005): In vivo effects of chronic contamination with depleted uranium on CYP3A and associated nuclear receptors PXR and CAR in the rat. Toxicology, 214, 113-122.

Souza, C.G., Moreira, J.D., Siqueira, I.R., Pereira, A.G., Rieger, D.K., Souza, D.O., Souza, T.M., Portela, L.V. and Perry, M.L. (2007): Highly palatable diet consumption increases protein oxidation in rat frontal cortex and anxiety-like behavior. Life Sci., 81, 198-203.

Thiels, E. and Klann, E. (2002): Hippocampal memory and plasticity in superoxide dismutase mutant mice. Physiol. Behav., 77, 601-605.

Videla, L.A. and Fernández, V. (1988): Biochemical aspects of cellular oxidative stress. Arch. Biol. Med. Exp.(Santiago), 21, 85-92.

Warner-Schmidt, J.L. and Duman, R.S. (2006): Hippocampal neurogenesis: opposing effects of stress and antidepressant treatment. Hippocampus, 16, 239-249. 